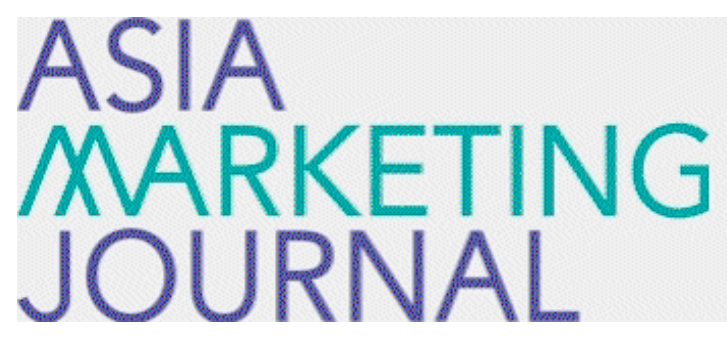

ASIA MARKETING JOURNAL

Volume 1 | Issue 4

Article 2

9-1-1999

\title{
내부서비스품질이 종업원만족과 고객만족에 미치는 영향에 관한 연구
}

동성 곽

기두 강

Follow this and additional works at: https://amj.kma.re.kr/journal

Part of the Marketing Commons

\section{Recommended Citation}

곽, 동성 and 강, 기두 (1999) "내부서비스품질이 종업원만쪽과 고객만족에 미치는 영향에 관한 연구," Asia Marketing Journal: Vol. 1 : Iss. 4 , Article 2.

Available at: https://doi.org/10.53728/2765-6500.1023

This Article is brought to you for free and open access by Asia Marketing Journal. It has been accepted for inclusion in Asia Marketing Journal by an authorized editor of Asia Marketing Journal. 


\title{
내부서비스품질이 종업원만족과 고객만족에 미치는 영향에 관한 연구*
}

\author{
곽 동 성(중앙대학교 경영대학 교수) \\ e-mail ; kwak@chungang.edu \\ 강 기 두(중앙대학교 경영대학 강사) \\ e-mail ; $\underline{\text { dugi@ } @ \text { chungang.edu }}$
}

\begin{abstract}
서비스는 기본적으로 고객과 서비스공급자간의 상호작용을 필요로 한다. 이때 서비스 공 급자 구체적으로 종업원들이 자신의 직무에서 느낀 것들이 서비스 조우시 그대로 고객에게 전달되게 된다. 즉, 기업의 최종 지향점인 고객만족을 위해 내부 고객인 종업원의 만족이 필 수적이라 할 수 있는데, 본 연구에서는 내부고객을 대상으로 한 내부마케팅 구체적으로 내 부고객에게 제공되는 서비스품질의 내용을 알아보기 위해 선행연구에 대한 포괄적인 검토를 통해 이를 파악하고, 종업원만족이나 고객만족 등의 후행변수에 어떠한 영향을 미치는지를 알아보고자 하였다. 이를 위해 병원에 근무하는 간호사들을 대상으로 실증분석을 실시하였 고, 연구결과 내부고객에게 제공되는 내부서비스품질이 높을수록 종업원만족이 상승함을 발
\end{abstract} 견하였다.

key word (1) 내부마케팅, (2) 내부서비스품질, (3) 고객만족, (4) 서비스능력

* 논문접수일: 99.8 게재 확정일: 99.11 


\section{1. 서 론}

생산과 소비의 비분리성이라는 서비스의 특성상 서비스의 생산 및 전달과정에서 종업원 과 고객은 서로 상호작용을 하게 된다. 이로 인해 종업원들이 자신의 직무에서 느낀 것들이 서비스조우(service encounter)시 그대로 고객에게 전달되게 된다(Schneider and Bowen 1993).

또한 고객은 자신의 서비스경험을 서비스를 제공하는 스텝이나 종업원에 의해 전달되는 지식 및 행동을 토대로 결정하기 때문에 종업원들에게 보다 고객지향적이고 서비스 지향적 인 마인드를 갖도록 할 필요가 있다(곽동성 강기두 1999).

이를 위해 외부고객(external customer)에게 서비스를 제공하는 종업원에게 마케팅철학과 기법을 적용할 필요성이 있으며, 기업의 입장에서 종업원을 내부고객(internal customer)으로, 직무를 내부제품(internal product)으로 감안하여 조직의 목표를 달성하려는 노력을 하는 한편 내부고객의 필요와 욕구를 충족시키는 보다 양질의 내부제품을 제공하려는 노력을 하는 내 부마케팅(Berry 1981)의 필요성이 제기된다.

즉, 노동집약적인 속성이 강한 서비스에서 핵심이 되는 활동으로서 종업원이 직무에 만 족할 수 있도록 직무환경을 조성해주고 또 마케팅기법을 활용하여 종업원이 고객지향적인 인식과 태도를 갖도록 동기부여하고 개발해주는 활동을 전개할 필요가 있으며, 이를 통해 고객만족을 달성할 수 있는 것이다(Rust et al., 1996).

서비스품질과 고객만족은 최근 서비스관련 연구에서 많은 비중을 차지하고 있으며, 연구 들에 따르면 높은 수준의 고객만족을 달성하기 위해서 기업은 제공하는 서비스의 내부요소 를 제대로 파악, 측정 및 관리할 필요가 있다고 한다. 즉, 고객만족을 위해서는 종업원에게 양질의 서비스를 제공함으로써 만족을 이루어야 하며, 종업원들이 자신의 직무에 대해 만족 하지 못할 경우, 고객들의 충성(loyalty)과 기업의 수익에 직접적인 영향을 미치는 고객만족 의 달성이 어렵게 된다(Rosenbluth 1991; Schlesinger and Heskett 1991).

결국 서비스기업은 고객에게 전달되는 서비스의 품질과 함께, 기업 전체적으로 내부서비 스품질에 주력할 필요가 있으며, 효율적인 내부서비스품질의 관리를 통해 고객들의 서비스 경험을 좋게 하고 이를 통해 고객만족을 달성할 수 있게 된다.

그러나 지금까지의 연구들은 외부고객에게 전달되는 서비스품질에 주력해 왔을 뿐, 내부 고객을 대상으로 하는 내부서비스품질에 대해서는 별로 이루어지지 않았다. 물론 내부서비 스품질에 대한 개념적인 연구(Zeithaml, Parasuraman, and Berry 1990; Berry and Parasuraman 1991) 들은 있었지만, SERVQUAL 을 이용하여 내부서비스품질에 대해 실증적인 규명을 시도한 
Chaston (1994)과 Edvardsson 등 (1997)이 연구를 제외하고는 실증적으로 검증하려는 시도는 드문 편이다. 그리고 전통적으로 인사관리의 영역에서는 종업원의 만족을 이끄는 요인으로 서 경제적 요인과 비경제적 요인이 존재한다고 제안하는데, 이 중 어떠한 요인이 종업원만 족에 보다 큰 영향을 미치는지에 대한 부분 역시 그 연구가 별로 진행되지 못하고 있는 실 정이다.

이러한 인식을 토대로 본 연구는 다음의 목적으로 진행되었다.

첫째, 포괄적인 선행연구의 검토를 통해 내부서비스품질의 개념적인 정의와 이의 측정방 안에 대해 알아보고자 한다. 특히 기존의 외부고객을 대상으로 수행된 서비스품질 측정방법 이 내부 고객인 종업원을 대상으로도 적용될 수 있는지를 파악해보고자 한다.

둘째, 서비스기관을 대상으로 한 실증분석을 통해 종업원에게 제공되는 내부서비스품질 이 종업원들의 서비스능력과 만족에 어떠한 영향을 미치며, 이와 함게 종업원들의 서비스능 력과 만족은 고객만족에 어떠한 영향을 미치는지를 알아보고자 한다.

셋째, 종업원만족에 영향을 미치는 요인들 중 보다 영향력이 큰 요인을 찾아봄으로써 서 비스종업원의 만족 그리고 관리에 대한 시사점을 제공하고자 한다.

\section{2. 이론적 고찰}

\section{1 내부마케팅(Internal Marketing)}

점차 서비스분야의 마케팅은 거래지향적에서 관계구축 지향적으로 그 패러다임을 변경해 가고 있다 (Berry 1983). 전자가 단기간의 목표달성을 지향한다면 후자는 장기적인 관계를 지 향한다고 할 수 있다. Grönroos(1990)는 이와 관련해서 '거래마케팅의 목적은 고객을 얻는 것 에 그치지만 관계마케팅은 고객을 얻고 이를 유지하는 것이 목적이다'고 정의하기도 하였다. 때문에 오늘날 내부마케팅은 외부 마케팅 및 상호작용적 마케팅과 함께 서비스기업이 포괄 적인 관계마케팅을 수립하는데 필수 불가결한 요소인 것으로 알려져 있다.

\subsection{1 내부마케팅의 정의}

내부마케팅이란 기업이 종업원에게 판매(selling)하는 것 (Grönroos 1990), 또는 종업원들의 니즈에 부합하는 직무관련 제품을 통해 자격을 갖춘 종업원을 유인, 개발, 및 확보하는 것 
(Berry and Parasuraman 1991)이며, 고객접촉 종업원과 지원 스텝들이 한 팀으로 활동하도록 하기 위한 훈련과 동기부여를 통해 종업원들에게 고객지향적인 사고를 심어주는 것이다 (Kotler and Armstrong 1991). 또한 George 와 Grönroos (1991)는 내부마케팅을 '종업원들의 내부 시장은 적극적이고 마케팅 식의 접근방법을 통해 서비스 지향적이고 고객지향적인 행동을 동기부여 할 수 있는 최고의 방법이다라고 하였다. 따라서 이러한 내부마케팅활동을 통해 보다 서비스 지향적이고 고객지향적인 종업원을 확보하게 되고, 이를 통해 고객만족과 고객 충성 등을 달성할 수 있게 된다.

이외에도 내부마케팅에 대한 개념들을 살펴보면 <표 $1>$ 과 같다.

<표 1> 내부마케팅에 대한 선행 연구들의 개념정의

\begin{tabular}{|c|c|c|}
\hline 연구자 & 연도 & 개념 정의 \\
\hline Sasser \& Arbeit & 1976 & 제품/서비스를 고객에게 팔기 전에 먼저 종업원에게 파는 활동 \\
\hline Berry & 1981 & $\begin{array}{l}\text { 내부고객으로서 종업원을, 내부제품으로서 직무를 생각하여 조직의 목표 } \\
\text { 를 달성하려는 노력을 하는 한편 내부고객의 필요와 욕구를 충족시키는 } \\
\text { 내부제품을 제공하려는 노력을 하는 것 }\end{array}$ \\
\hline Grönroos & 1981 & $\begin{array}{l}\text { 고객지향적 성과를 달성하기 위하여 내부시장으로서의 종업원을 적극적 } \\
\text { 인 마케팅지향적 접근방법에 의하여 실현하는 수단의 집합 }\end{array}$ \\
\hline Normann & 1984 & $\begin{array}{l}\text { 서비스제공에 있어 품질유지, 높은 생산성으로 비용절감, 동기화된 종업 } \\
\text { 원을 통해 고객에 대한 중요한 이미지 표현 등을 달성하기 위한 수단 }\end{array}$ \\
\hline George & 1990 & $\begin{array}{l}\text { 서비스기업의 첫 번째 시장은 종업원이라는 관점에서 고객에게 서비스를 } \\
\text { 알리고 설득하기 전에 먼저 종업원에게 서비스가 제공하려는 편익을 알 } \\
\text { 리고 설득하고 교육시켜 내부시장의 욕구를 먼저 충족시키는 활동 }\end{array}$ \\
\hline $\begin{array}{c}\text { Wasmer \& } \\
\text { Brunner }\end{array}$ & 1991 & $\begin{array}{l}\text { 서비스품질에 대하여 종업원의 긍정적인 태도를 촉진하고 고객서비스의 } \\
\text { 가치에 대하여 종업원의 의식을 제고하는 활동 }\end{array}$ \\
\hline $\begin{array}{l}\text { Bak, Vogt, } \\
\text { George } \\
\& \text { Greentree }\end{array}$ & 1994 & $\begin{array}{l}\text { 외부시장에서 목표를 달성하기 위해서는 조직과 종업원 사이의 내부교환 } \\
\text { 이 효과적으로 운영되도록 하는 활동 }\end{array}$ \\
\hline $\begin{array}{l}\text { Rust, Zahorik } \\
\& \text { Kenningham }\end{array}$ & 1996 & $\begin{array}{l}\text { 내부마케팅은 훈련, 경영자의 계속적 유대, 내부의사소통, 마케팅조사, 기 } \\
\text { 타 인적자원활동으로 구성됨 }\end{array}$ \\
\hline $\begin{array}{l}\text { Kotler, Bowen } \\
\& \text { Makens }\end{array}$ & 1996 & $\begin{array}{l}\text { 내부마케팅은 조직문화의 확립, 인적자원관리의 마케팅적 접근방법 개발, } \\
\text { 종업원에 대한 마케팅정보의 전달 그리고 보상과 표창에 대한 실행 과정 } \\
\text { 이다. }\end{array}$ \\
\hline
\end{tabular}

이러한 견해들을 종합해서 Joseph (1996)은 내부 마케팅에 대해 "외부고객에게 서비스하 는 방법을 지속적으로 개선하기 위한 종업원의 동기부여를 위해 마케팅, 인사관리 및 관련 이론과 기술 및 원칙 등을 응용한 것"이라고 폭 넓게 정의 내리고 있다. 이러한 Joseph 의 정의는 '고객 지향적'이라는 개념이 내부고객뿐만 아니라 외부고객에까지 넓게 적용되어야 
함을 제시하고 있다. 또한 Gremler 등 (1994)은 종업원이 속해있는 기업에 대한 종업원만족 은 내부 서비스공급업자(예를 들어서 병원에서 종양학 부서의 경우 병리실험실)와의 서비스 접촉에 유의한 영향을 받는다고 제시해주고 있다.

이러한 견해를 종합적으로 반영하면 다음 <그림 1>과 같이 내부마케팅, 외부마케팅, 그 리고 상호작용적 마케팅의 영역을 구별해볼 수 있다.

이렇게 내부마케팅의 영역은 서비스기업내의 모든 종업원들을 대상으로 하는 것이 가장 바람직하다고 할 수 있지만 본 연구에서는 우선 고객들과 직접적으로 접촉하는 현장종업원 을 대상으로 연구를 진행하게 된다.

<그림 1> 병원의 마케팅시스템

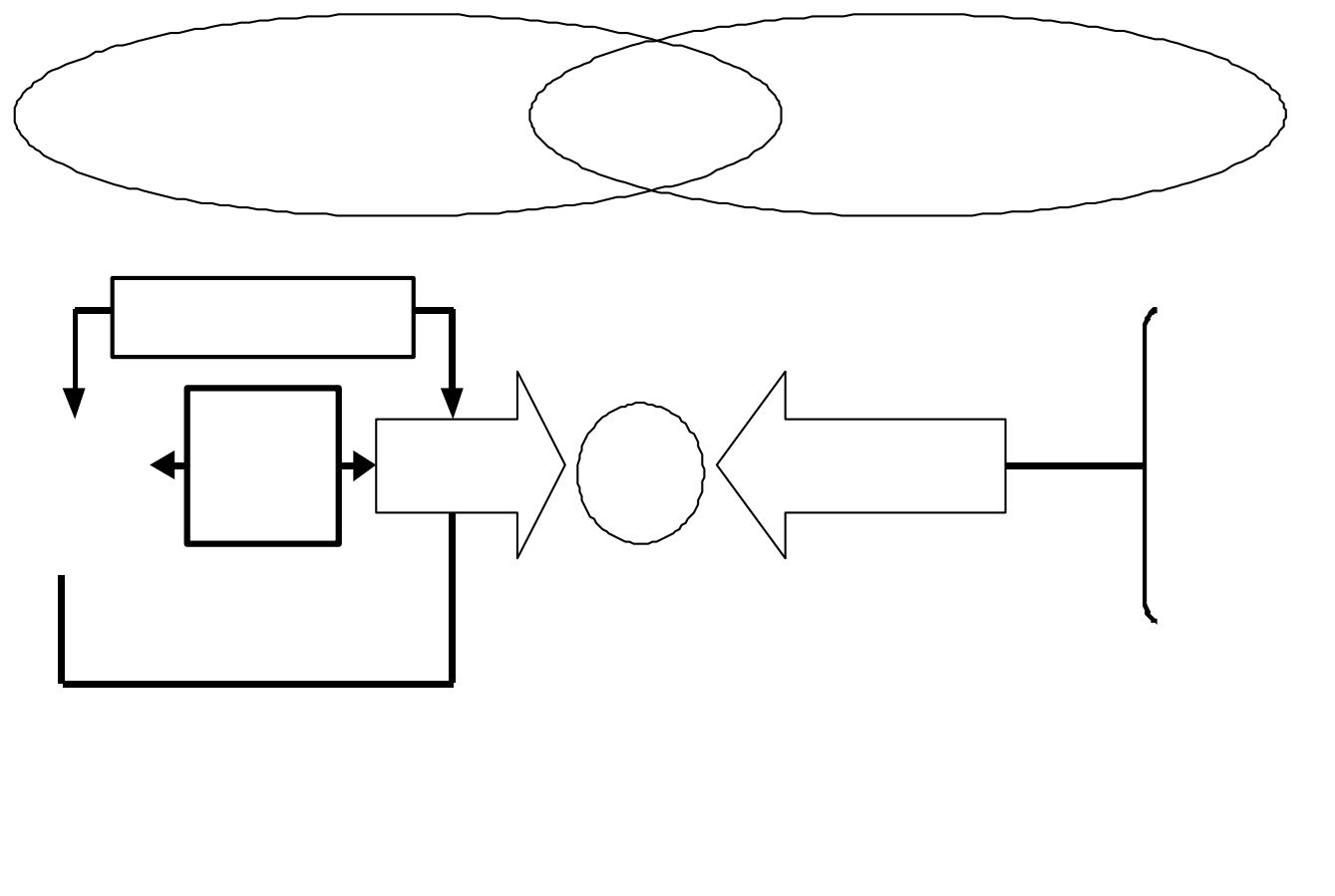

자료원 : Joseph, W. B. (1996), "Internal Marketing Builds Service Quality," Journal of Health Care Marketing, Vol.16, No.1, p.56.

\subsection{2 내부마케팅의 목적}

내부마케팅은 종업원들에게 새로운 제품이나 서비스를 도입하거나 새로운 마케팅활동을 시작할 때 종업원들이 이러한 내용들을 충분히 이해하거나 수행하지 못한 부분을 해결해주 기 위해 도입된 측면도 강하다. 이러한 관점에서 내부마케팅의 목적은 다음과 같이 정리할 수 있다(Grönroos 1990).

첫째, 종업원들이 고객지향적이고 서비스마인드를 갖출 수 있게끔 동기부여하고, 그에 따 
라 자신들의 직무를 성공적으로 수행할 수 있도록 한다.

둘째, 유능한 종업원을 모집하고 확보한다.

물론 내부마케팅의 주요목적은 인적자원을 제대로 관리하고 내부행동 프로그램을 시행함 으로써 종업원들이 본인의 소속 부서와 관계없이 마케팅요원으로서의 행동을 하게끔 동기 부여하는 것이다. 이러한 종업원에 대한 효율적인 동기부여의 방안으로는 기업의 사명, 전략, 서비스제품, 광고캠페인 등을 종업원에게 이해/수용시킴으로서 종업원의 참가를 촉진하고 우수한 업무를 수행할 수 있게 된다. 그리고 두 번째의 목적은 첫 번째의 목적이 달성되고 나서 이루어질 수 있는 것이라 할 수 있는데, 내부마케팅이 효율적으로 수행될수록 근로자 들은 그 기업에 대해 보다 큰 매력을 느끼게 될 것이다.

\section{2내부서비스품질(Internal Service Quality)}

내부마케팅의 관점에 따르면 외부고객에게 양질의 서비스를 제공하려는 기업은 반드시 기업내부의 고객, 즉 종업원들의 욕구에 부합하는 활동을 먼저 전개해야만 한다. 즉, 종업원 들에게 제공되는 내부서비스품질은 외부고객에게 제공되는 외부서비스품질의 전제 조건이라 할 수 있다 (Schlesinger and Heskett 1991).

또한 서비스기업에 있어서 종업원만족과 동기부여정도는 고객에게 제공되는 서비스의 품 질을 결정하는데 있어 매우 핵심적인 요인이며 (Rosenbluth and Peters 1992), 서비스의 특성상 고객들이 서비스생산과정에 직접 참여하기 때문에, 고객들은 서비스공급자의 만족 등을 부 분적으로나마 지각할 수 있게 된다. 이러한 요인들로 인해 기업입장에서 볼 때 내부 고객에 게 제공되는 내부서비스품질의 중요성이 커지게 된다.

그러나 지금까지 내부서비스품질에 대한 연구는 그리 큰 주목을 받지 못하였던 분야였다. 특히 그 구성요인들이 기업에 따라서 그리고 시기에 따라서 달라질 수밖에 없기 때문에, 이 론적인 면에서의 연구는 진행되었지만 실증적인 연구가 미약한 실정이다. 이 때문에 내부서 비스품질에 대한 연구는 기존에 진행된 품질 및 서비스품질 연구에서 많은 부분을 응용하여 진행해왔다.

이러한 맥락에서 서비스품질관련 문헌을 살펴보면 몇 가지 두드러진 점을 발견할 수 있 다. 우선, 품질 특히 서비스품질은 정의하기가 어렵고, 그 정의는 고객의 관점에 따라 달라 지게 된다. 때문에 내부고객, 즉 종업원 역시 자신들에게 제공되는 서비스의 품질에 대해 상 
이한 견해를 가질 수 있다.

Heskett 과 Schlesinger (1994)는 내부서비스품질을 '사람들이 서로에 대해서 가지고 있는 태도이며 사람들이 조직 내에서 서로 대우하는 방법'이라고 정의하였다. 이러한 정의는 서비 스품질을 태도로써 가장 잘 개념화할 수 있다는 Cronin 과 Taylor (1992)의 주장과 일치하는 것이다. 결국 제공 받는 내부고객들에게 제공되는 내부서비스품질을 명확하게 인식할 필요 가 있음을 제기한다.

그러나 앞서 언급한 대로 내부서비스 품질을 규명하기 위한 개념적 연구는 있어왔지만, 실증적인 연구는 몇몇 연구를 제외하고는 미미한 실정이다(Stanley and Wisner 1998; Hallowell, Schlesinger, and Zornitsky 1996).

Zeithaml 등(1990)은 내부서비스품질을 자신들이 주장한 서비스품질 격차 중 격차 3 , 즉 전달 격차(Delivery Gap ; 서비스 품질 명세 - 서비스 전달 차이)와 관련된 것이라고 하고, 이 러한 격차를 해소하기 위한 수단으로서 7 가지를 제시하였다. 그리고 Berry 와 Parasuraman (1991)은 자격을 갖춘 종업원을 모집, 개발 및 확보하기 위해 내부마케팅이 필요하다고 하면 서, 이를 위한 수단으로서 7 가지의 방안을 제시하였으며, Hallowell 등(1996)은 내부서비스품 질에 대해 개념적으로 이뤄진 선행 연구들을 종합하여 8 가지의 내부서비스품질 구성요인을 제안하였다. 이들의 연구를 정리하면 <표 2>와 같다.

<표 2 > 내부서비스품질에 대한 선행연구 요약

\begin{tabular}{|c|c|c|c|}
\hline \multirow{2}{*}{ SERVQUAL 차원 } & $\begin{array}{c}\text { Hallowell et al. } \\
(1996)\end{array}$ & $\begin{array}{c}\text { Berry 와 Parasuraman } \\
(1991)\end{array}$ & $\begin{array}{c}\text { Zeithaml et al. } \\
(1990)\end{array}$ \\
\hline \multirow{2}{*}{ 신뢰성(reliability) } & 효율적 훈련 & 역할갈등의 제거 & 적절한 교육 \\
\cline { 2 - 5 } & 목표의 공유 & 종업원 역할 명료성 & 비전의 제공 \\
\hline \multirow{2}{*}{ 확실성(assurance) } & 보상과 인정 & $\begin{array}{c}\text { 성과에 대한 측정과 } \\
\text { 보상 }\end{array}$ & 적절한 측정과 보상 \\
\hline 유형성(tangibles) & 도구 & - & - \\
\hline \multirow{3}{*}{ 공감성(empathy) } & 커뮤니케이션 & & 종업원의 이해 \\
\cline { 2 - 5 } & 팀웍 & 팀웍의 구축 & 팀플레이 장려 \\
\cline { 2 - 5 } & 관리자의 지원 & 종업원의 자율성제고 & 자율성 제고 \\
\hline 반응(responsiveness) & 정책과 절차 & - & - \\
\hline & - & 외부고객관리 & - \\
\hline
\end{tabular}

<표 2>에서 나타난 연구들을 종합해보면, 내부서비스품질 측정문항 개발을 위한 아이디 
어를 발견할 수 있다. 즉, 각 학자들이 내부서비스품질에 대해 정의 내리면서 각 개념을 설 명하고 측정했던 내용과 Parasuraman 등(1985)이 서비스품질의 측정도구로 제안한 SERVQUAL 의 각 측면(dimension)에 대한 설명 및 문항들과 비교해 보면 대부분 SERVQUAL 에서 제안하는 다섯 가지 차원, 즉 신뢰성(reliability), 확실성(assurance), 유형성 (tangibles), 공감성(empathy), 반응(responsiveness)에 응용할 수 있음을 발견할 수 있다.

실제로 Chaston (1994)은 서비스품질에서의 잠재적인 격차(gap)의 존재여부를 알아보기 위 해 SERVQUAL 을 이용해서 내부환경을 실증적으로 검증하였다. 연구결과 기업들이 내부 고 객들의 니즈보다 효율성에 더 비중을 두고, 내부 고객들의 욕구를 이해하려는 노력을 기울 이지 않기 때문에 서비스품질에 격차가 존재한다는 사실을 밝히고, 내부고객과의 관계를 제 대로 관리할 수 있는 표준을 제시하였다. Edvardsson 등 (1997)도 SERVQUAL 을 이용하여 종 업원들에게 제공되는 내부서비스품질과 심리적인 작업환경간의 상호관련성이 있음을 실증적 으로 검증하였다. 이에 본 연구에서도 내부서비스품질의 측정은 SERVQUAL 의 문항을 응용 하여 이용하기로 한다.

\section{3 종업원만족}

고객만족뿐만 아니라 종업원만족에 대한 연구는 대부분의 품질지향적인 기업전략에 있어 서 핵심적인 사항이다(Fosam et al. 1998). 특히 종업원이 고객과 직접적으로 접촉하는 경우에 특히 그러한데, 종업원 만족을 달성하게 되면 고객만족을 확보할 수 있다(Rust et al., 1996). 특히 내부마케팅은 기본적으로 기업을 구성하는 모든 구성원들 - 내부 고객이든 외부 고객 이든 - 의 만족을 지향한다.

기본적으로 서비스조직에서는 종업원과 소비자는 매우 빈번하게 상호작용을 한다. 따라 서 종업원들이 느끼고 경험하는 것들은 서비스조우(service encounter)시 고객에게 그대로 전 달될 수밖에 없다. Schneider 와 Bowen (1993)은 종업원들이 자신들의 직무에 대해 경험한 것 을 제대로 파악하고 있는지의 여부는 고객들이 서비스품질을 어떻게 지각하는지에 통계적으 로 유의한 영향을 미친다고 하였다. 즉 종업원들에게 긍정적인 경험을 심어줌으로써 외부고 객의 시각에서 고품질의 서비스를 지각할 수 있도록 하는 결과를 초래할 수 있다는 것이다 (Edvardsson et al 1997).

이를 위해 서비스기업들은 외부고객에 대한 품질 지향뿐만 아니라 내부 고객들에게도 이 를 강조하는, 전 조직에 걸쳐 품질 지향적인 경영철학을 갖추고 있지 않으면 안 된다.

전통적으로 인사관리영역에서는 종업원들의 만족제고를 위해서 공정성(fairness)라는 개념 
을 들면서 이를 설명해주고 있다. 즉 기업이 종업원들을 공정하게 대우하면, 혹은 종업원들 이 공정하게 대우 받는다는 생각을 갖게 되면 이는 조직에 대한 몰입(commitment)을 높여준 다는 것이다(Bowen et al. 1999). 또한 Bowen 등 (1999)은 외부고객의 관점에서도 종업원들이 공정하게 대우 받게 되면 그것이 서비스경험 - 서비스전달과정(service delivery)과 서비스회복 (service recovery)- 을 통해서 느낄 수 있게 된다고도 하였다.

그러나 품질 지향적인 경영 속에서 종업원만족은 인적자원관리 부서의 담당자뿐만 아니 라 마케팅 담당자에게도 중요한 문제일 수밖에 없으며 이로 인해 종업원 만족에 관한 체계 적인 연구의 필요성이 제기 된다.

종업원만족을 위해서는 이들의 욕구를 충족시켜주어야 하는데, 연구에 따르면 종업원의 욕구는 직무와 관련된 과업과 같은 내적(content)요인과 임금,신분안정,감독,역할갈등,조직구 조,직무분위기와 같은 직무의 외재적인 면을 포괄한 외적(context)요인으로 구분한다. 그리고 외적(context)요인은 다시 경제적(예를 들면, 임금)요인과 비경제적인 요인으로 구분한다.

위의 종업원만족에 영향을 미치는 제 요인들간의 상대적 영향력에 대해서는 우선 내적 요인보다는 외적요인이 종업원만족과 높은 상관관계를 가진 것으로 나타났고(Atkins et al., 1996), 그 외적 요인 중에서도 비경제적 요인이 경제적요인보다 종업원만족에 상대적으로 큰 영향을 미치는 것으로 나타났다(Hallowell et al., 1996).

특히 Hawllowell 등 (1996)은 <표 2>에서 제시한 것처럼 종업원만족에 영향을 미치는 비 경제적 요인들을 내부서비스품질이라고 규정하면서 경제적요인과의 상대적 영향력을 실증적 으로 비교하였다.

이러한 연구를 종합해보면, 종업원 만족은 주로 직무 자체가 아닌 직무의 외재적인 면인 외적(context)인 요인에 의해 결정되며, 종업원 만족의 외적요인은 다시 경제적인 요인과 비 경제적 요인으로 나누어 볼 수 있으며 본 연구에서 알아보고자 하는 내부서비스품질은 외적 요인중의 하나인 비경제적 요인으로 간주할 수 있게 된다. 본 연구에서는 이를 토대로 연구 를 진행하게 된다.

\section{4 고객만족}

고객만족은 모든 기업이 추구해야 할 궁극적인 목적이다. 고객만족이 가지는 가치 즉, 반 복구매, 재구매 의도 및 우호적인 구전에 직접적인 영향을 미치는 속성은 마케팅활동에서 가장 핵심적인 변수의 역할을 가지게 된다. 다시 말해서 고객만족은 고객의 욕구나 기대에 대한 서비스제공능력의 평가치와 구매 후 행동에 대한 효과적인 예측치의 성격을 가지기 때 
문에 그 중요성이 큰 것이다.

고객만족에 대해서는 다양한 상황에서 다양한 방법론이나 측정치를 이용하여 측정되어 왔다. 그러나 아직까지 의료기관의 이용자인 환자들을 대상으로 한 고객만족 조사는 거의 이루어지지 않고 있다.

\section{3. 연구의 모형 및 가설설정}

\section{1 연구의 모형}

서론에서 제시한 바와 같이 본 연구에서는 내부서비스품질에 대한 선행연구 검토와 내부 서비스품질이 종업원만족과 이들의 서비스능력에 어떠한 영향을 미치는지, 그리고 최종적으 로 고객만족에는 어떠한 영향을 미치는지를 알아보고, 이와 함께 종업원만족에 영향을 미치 는 것으로 알려진 외적(context)요인들 중에서 어떤 속성(경제적 요인 또는 비경제적 요인) 이 보다 중요한 영향을 미치는지를 알아보고자 한다. 이에 따라 <그림 2>와 같은 연구모형 을 제시할 수 있다.

\section{<그림 2> 연구의 모형}

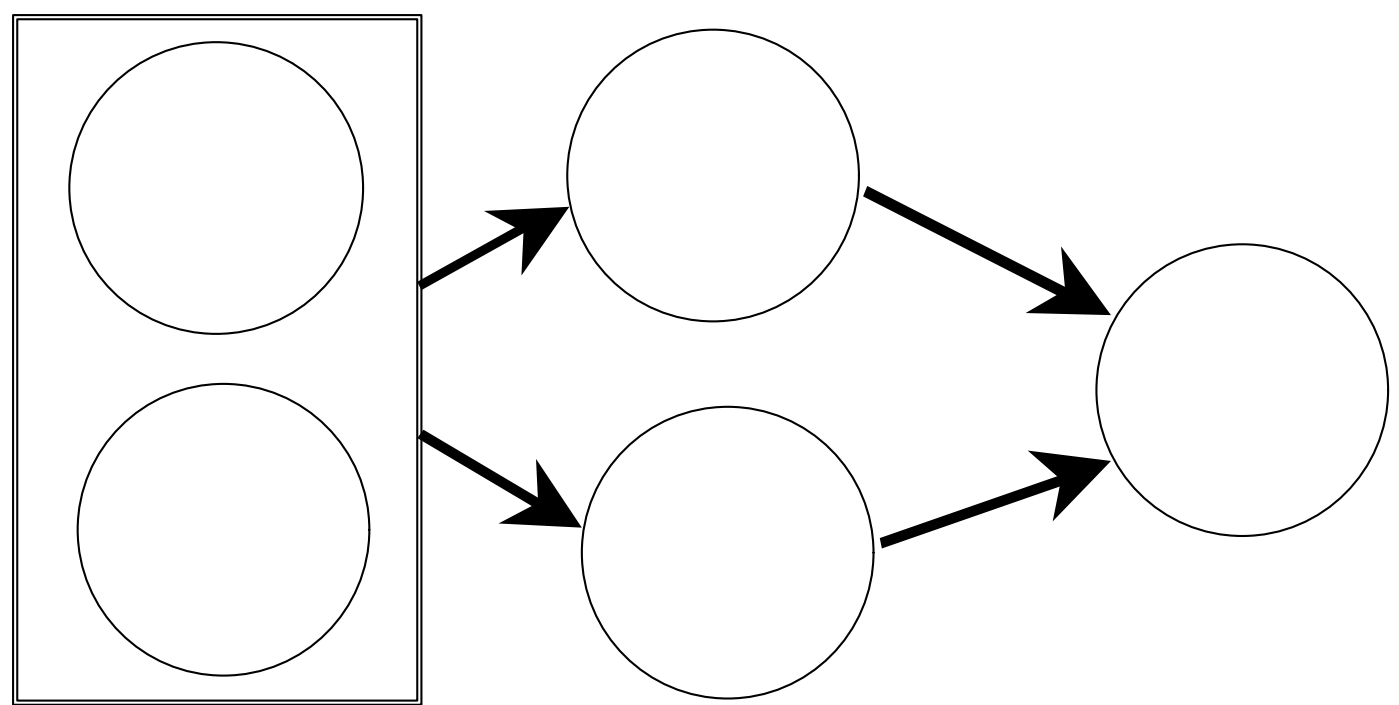

${ }^{1}$ 여기서는 내부서비스품질을 가리킴 


\section{2 가설의 설정}

고객만족을 증진시키기 위해서는 즉각적인 서비스, 예의 바른 행동, 그리고 고객욕구의 이해와 같은 속성들을 서비스제공자, 구체적으로 종업원들이 갖추어야만 한다(Zeithaml et al. 1990). 그러나 여러 가지 이유로 인해서 종업원들이 고객만족을 유도할 수 있는 서비스행동 을 수행할 수 없게 하는데, 이를 위해 적절한 내부마케팅 활동을 펼칠 필요가 있다.

때문에 기업입장에서 고객들과 직접 접촉하는 서비스 종업원들에게 보다 양질의 서비스 를 제공할 필요가 있으며, 이를 통해 종업원들의 서비스제공능력이 향상되고 이를 통한 고 객만족 달성이 가능해질 것이다. 이러한 점을 토대로 다음과 같은 연구가설을 설정할 수 있 다.

H1 : 기업이 종업원에게 제공하는 내부서비스품질이 상승하면 종업원의 서비스능력은 상승할 것이다.

H2 : 기업이 종업원에게 제공하는 내부서비스품질이 상승하면 종업원 만족이 높아질 것이다.

H3 : 서비스능력이 높아지면 고객만족이 높아질 것이다.

H4 : 종업원 만족이 높아지면 고객만족이 높아질 것이다.

일반적으로 종업원 만족을 제고하기 위한 방안으로는 인사조직영역의 직무몰입분야에서 주로 다루었던 부분들이었다. 해당 연구들이 중심으로 다루었던 것은 종업원들의 성과와 직 무만족은 종업원들의 욕구(needs)를 어떻게 달성시킬 것인가와 관련된 것이었다. 그런데 종 업원들의 욕구는 크게 경제적인 욕구와 비경제적인 욕구로 구별할 수 있는데(Hallowell et al. 1996), 본 연구에서는 내부서비스품질의 제고를 통해 종업원 만족을 증진시킬 수 있다고 하 였다. 이에 다음과 같은 연구가설을 설정하여 종업원 만족에 유의한 영향을 미치는 변수를 밝혀볼 수 있을 것이다.

H5 : 종업원의 서비스능력은 경제적 요인(임금이나 복지)보다 내부서비스품질과 같은 비경제적 요인의 영향을 더 받을 것이다.

H6 : 종업원 만족은 경제적 요인(임금이나 복지)보다 내부서비스품질과 같은 비경제 적 요인의 영향을 더 받을 것이다. 


\section{4. 연구의 방법}

\section{1 연구의 표본}

본 연구의 목적을 달성하기 위해서는 서비스를 제공하는 종업원에 대한 조사가 이루어져 야 하는데, 본 연구에서는 이를 위해 서울시내에 소재한 모 병원 소속의 간호사들을 대상으 로 설문조사를 실시하였다. 특히 종업원만족과 고객만족과의 관련성을 알아보기 위해 고객 만족 설문지의 경우는 특정 부서의 서비스를 이용하고 난 후의 만족여부 등을 알아보도록 하였다.

설문조사는 총 250 부의 설문지를 배포하여 총 190 부가 회수되었으며, 이중 불성실한 답 변 내지는 일부 답변이 누락되는 등 분석에 부적합한 설문지를 제외하고 126 부(66.3\%)만이 실증분석에 이용되었다.

본 연구의 대상이 된 응답자들의 특성은 <표 3 >과 같다.

<표 3> 표본의 일반적 특성

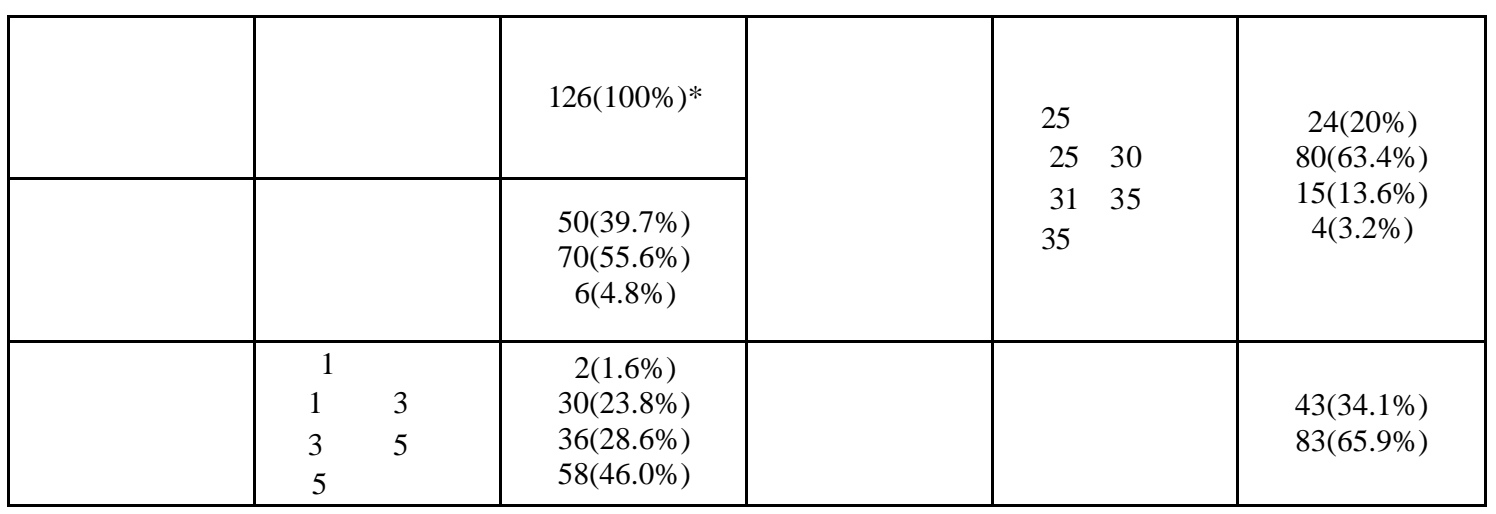

\section{2 변수의 조작적 정의와 측정}

(1) 내부서비스품질(Internal Service Quality) : 내부서비스품질은 "조직 내에서 사람들이 서 로에 대해 가지고 있는 태도로서 서로 대우하는 방법”으로서 본 연구에서 이용한 내부서비 스품질의 측정문항은 <표 2>에서 밝힌 것처럼 Parasuraman 등 (1988)이 제안한 SERVQUAL 을 기반으로 하고 있다. 본 측정도구는 개발자들이 고객들의 서비스품질 지각에 대한 실증 연구를 토대로 5 개 차원으로 축약한 것이다. 애초에 SERVQUAL 은 고객들의 서비스품질 지 
각측정을 위해 개발되어졌기 때문에 본 연구의 대상인 종업원들에 맞춰 일부 항목의 경우 워딩을 하였고, 이를 종업원들의 내부서비스품질 측정의 측정도구로 활용하였다.

애초 SERVQUAL 의 측정문항은 총 22 개 문항으로 이루어져 있지만, 본 연구의 대상으로 한 병원서비스의 상황에 부적합한 일부 문항을 제거하여 각 측면 당 4 개 문항씩 총 20 개 문항만을 리커트식 7 점 척도를 이용하여 측정하였는데, 이러한 방법은 Parasuraman 등 (1993)이 SERVQUAL 의 응용방법에 대해 제안했던 점에 비추어 볼 때 타당하다 할 수 있다.

(2) 서비스능력(service capability) : 서비스능력은 종업원들이 스스로 자신이 고객에게 서비 스를 수행할 수 있는 능력에 대해 지각하는 것으로써 본 항목은 내부서비스품질의 속성과 종업원 만족 그리고 고객만족을 매개해주는 역할을 하게 된다. 본 항목의 측정을 위해 본 연구에서는 '전반적으로 지각한 자신의 서비스능력'을 묻는 단일문항으로 '매우 낮다'에서 '매 우 높다'의 어의차이척도로 측정하였다.

(3) 종업원만족과 고객만족 : 대개 만족에 대한 측정은 '서비스에 대한 전반적인 만족도' 나 '특정 서비스경험에 대한 전반적인 만족도'를 묻는 것이 일반적이지만, 이러한 단일항목 (single-item) 측정방안은 종업원이나 고객들의 만족을 정확하게 측정할 수 없을 뿐만 아니라, 잘못된 결과를 유도할 수 있다고 한다.

또한 종업원만족에 대해서는 종업원 이탈율(turnover)이 대체측정변수로 많이 이용되지만, 본 연구에서는 병원의 경우 타 직종에 비해 종업원 이탈이 많지 않다는 점과 마케팅 영역에 서 활용하는 만족지수(satisfaction index)를 활용하는 것이 측정의 내적 일관성 유지 측면에서 바람직하다는 측면에서 이용하지 않았다.

이에 따라 본 연구에서는 다 항목(multi-item)측정방법을 이용하기로 하였으며, 구체적으 로 Atkins 등 (1996)이 병원 간호사들을 대상으로 만족도를 측정했던 문항들을 이용하여 '전 반적인 만족도', '근무지의 추천의지', '직장으로서의 추천의지', '이직의도'의 4 개 항목을 질문 하였고 '전혀 그렇지 않다'에서 '매우 그렇다'의 리커트 식 7 점 척도로 측정하였다.

그리고 고객만족은 '종업원의 기술(skill)', '종업원의 관심정도(attention)', '종업원의 응답정도 (response)', '종업원들의 태도(attitude)'의 7 개 항목에 대해 종업원들의 생각에 고객들이 그렇 게 생각할 것이다라는 식의 질문 하였으며, 모든 문항은 '전혀 그렇지 않다'에서 '매우 그렇 다'의 리커트 식 7 점 척도로 측정하였다.

(4) 경제적편익 : 종업원 만족을 이끌 수 있는 제 요인 중에서 경제적인 요인에 해당되는 임금과 편익은 종업원들에게 제공되는 금전적인 제반 혜택으로서, 본 연구에서는 Hallowell 등 (1996)이 연구에서 이용한 문항과 실증대상으로 삼은 병원의 인사관리자와의 면담 등을 
토대로 '봉급의 적정성,' '복리후생체제의 적정성,' '임금결정 정책과정이나 관리과정의 적절성,' '직무간 임금격차의 적정성'의 4 개 문항을 리커트식 7 점 척도를 이용하여 측정하도록 하였 다.

\section{3 실증분석의 방법}

본 연구에서는 우선 척도의 정제(scale refinement)를 위해 LISREL 을 이용하여 각 구성개 념(construct)에 대한 확증적요인분석(Confirmatory Factor Analysis)을 실시하고 함께 Cronbach' $\mathrm{a}$ 를 계산하였다. 그 결과 정제된 변수들을 이용하여 가설을 검증하게 되었다. 그리고 가설 의 검증은 공변량구조모형으로 검증되었는데, 이를 위해 LISREL 8.03 을 사용하였다. 이때 제안된 모형의 적합도를 평가하기 위해 여러 가지 지표를 이용하였는데, $\chi^{2}$ 치와 그 확률치 는 모델을 자료에 적용시킬 때 모델이 얼마나 경험자료에 잘 맞는가를 나타내는데 훌륭한 모델은 $\chi^{2}$ 치가 관련된 자유도(d.f.)에서 작을수록 바람직하고, 기초부합치(Goodness Fit Index: $\mathrm{GFI}$ 는 다중회귀분석에서의 $R^{2}$ 와 같은 의미로 자료의 변량, 공변량 가운데 예측된 변량, 공변량에 의해 설명되는 부분의 비율을 나타낸다. 보통 0 과 1 사이에 있는 기초부합치는 이 론적으로 음수가 될 수도 있는데, Silvia (1988)는 표본 크기가 200 이상에서 기초부합치가 적 어도 0.90 이상이라야 모델에 큰 문제가 없다고 하였다. 이러한 기초부합치를 자유도에 대해 수정한 것으로 조정부합치(AGFI: Adjusted Goodness Fit Index)가 있다. 마지막으로 원소간 평균 차이(RMR: Root Mean Square Residual)는 분석자료의 매트릭스와 모수들에 의해 재생산된 매 트릭스간에 원소들이 얼마나 차이가 있는가를 보여주며, 0.05 이하가 바람직하다고 한다.

\section{5. 실증분석의 결과}

\section{1 척도의 정제}

(1) 단일차원성 검정

본 연구에서는 다 항목을 이용한 각 차원들에 대한 단일차원성(unidimensionality)을 검정 하기 위해 LISREL 을 이용하여 확증적 요인분석을 실시하였고, 분석결과 남은 항목들을 대 상으로 Cronbach' $\alpha$ 를 계산하였다. 
<표 4> 각 구성개념별 확증적 요인분석 결과 및 신뢰성 검증

\begin{tabular}{|c|c|c|c|c|c|c|c|c|c|}
\hline \multicolumn{2}{|c|}{ 구성개념 } & $\begin{array}{c}\text { CFA 이전 } \\
\text { 흥목수 }\end{array}$ & $\begin{array}{c}\text { CFA 이후 } \\
\text { 흥목수 }\end{array}$ & GFI & AGFI & RMSR & $\chi^{2}$ & $\mathrm{p}$ & $\begin{array}{c}\text { Cronbach } \\
\text { ' } \mathrm{a}\end{array}$ \\
\hline \multirow{5}{*}{$\begin{array}{c}\text { 내부 } \\
\text { 서비스 } \\
\text { 품질 }\end{array}$} & 유형성 & 4 & 4 & 0.91 & 0.86 & 0.09 & 24.93 & 0.001 & 0.7056 \\
\hline & 신뢰성 & 4 & 4 & 0.98 & 0.90 & 0.04 & 5.60 & 0.061 & 0.7526 \\
\hline & 반응성 & 4 & 4 & 0.96 & 0.81 & 0.04 & 9.34 & 0.009 & 0.8362 \\
\hline & 확실성 & 4 & 4 & 0.98 & 0.92 & 0.03 & 4.22 & 0.120 & 0.7672 \\
\hline & 공감성 & 4 & 4 & 0.98 & 0.88 & 0.04 & 6.99 & 0.030 & 0.7962 \\
\hline \multicolumn{2}{|c|}{ 경제적요인 } & 4 & 4 & 1.00 & 0.98 & 0.02 & 1.29 & 0.520 & 0.7850 \\
\hline \multicolumn{2}{|c|}{ 직무만족 } & 4 & 4 & 0.99 & 0.96 & 0.02 & 1.87 & 0.390 & 0.7979 \\
\hline \multicolumn{2}{|c|}{ 고객만족 } & 4 & 4 & 0.93 & 0.76 & 0.06 & 16.88 & 0.0002 & 0.8244 \\
\hline
\end{tabular}

각 구성 개념들을 구성하는 측정 항목들에 대한 분석결과는 <표 4 >와 같으며, 대부분의 연구단위의 항목들은 적합도 평가기준을 어느 정도 충족시키는 것으로 나타나 단일 차원성 을 저해하지 않는 것으로 판단하고 다음 단계의 분석을 실시하였다.

(2) 내부서비스품질 측정 항목들의 처리

내부서비스품질에 대한 측정변수로 이용한 SERVQUAL 의 5 개의 개별차원별로 각 항목 들의 평균값을 이용하여 공변량구조분석 모형에서 기능적 품질의 측정변수로 사용하였는데 이는 Price 등 (1995)이 만족의 개념을 측정할 때 만족의 측정문항을 요인 분석한 후 요인으 로 적재된 문항들의 평균값을 측정변수로 사용한 것과 유사한 방법으로서 다수의 설문문항 을 소수의 차원으로 축약할 필요가 있을 경우에 일반적으로 요인점수(factor score)나 요인문 항의 합(factor mean)을 사용하여 추가분석에 활용하는 경우와 같은 원리이다. 또한 국내연구 중에서 이학식 등 (1998)도 시장지향성의 항목들을 가중 평균하여 하나의 종합적 지표를 구 하는 방식을 취하기도 하였다.

본 연구에서 다루는 구성개념들간의 인과관계를 측정항목들과 함께 나타내면 <그림 3> 과 같다. 
<그림 3> LISREL 분석을 위한 모형도

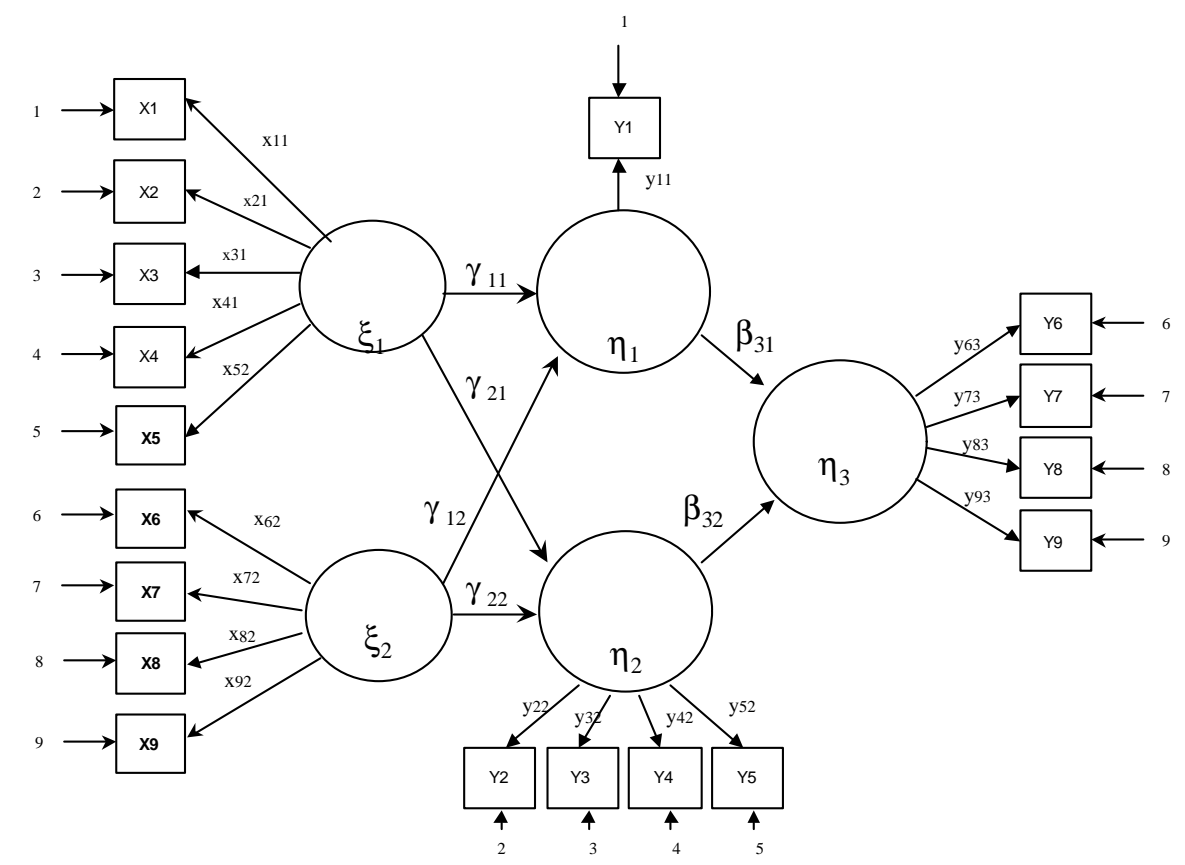

(3) 상관관계분석

확증적요인분석결과 단일차원성이 입증된 각 구성개념별 척도들에 대하여 서로의 관계가 어떤 방향이며, 어느 정도의 관계를 갖는지를 알아보기 위하여 상관관계분석을 실시한 결과 <표 5>와 같이 나타났다.

<표 5>에 나타난 바와 같이 본 연구에서 검토하고자 하는 모든 구성개념들의 관계가 모 두 정(+)의 상관관계로 나타났으며, 이로 미루어 연구모형과 연구가설에서 제시한 변수들간 의 관계의 방향은 일치하는 것으로 나타났다. 또한 동일한 개념을 측정하는 다른 측정치들 과의 상관관계가 상이한 개념을 측정하는 다른 측정치들과의 상관관계보다 대부분 더 높게 나타나 모든 측정치들이 집중타당성(convergent validity) 및 판별타당성(discriminant validity)을 갖고 있는 것으로 나타났다.

<표 5> 각 구성개념들간의 상관관계행렬 
한 국 마 케 팅 저 널 제 1 권 제 4 호

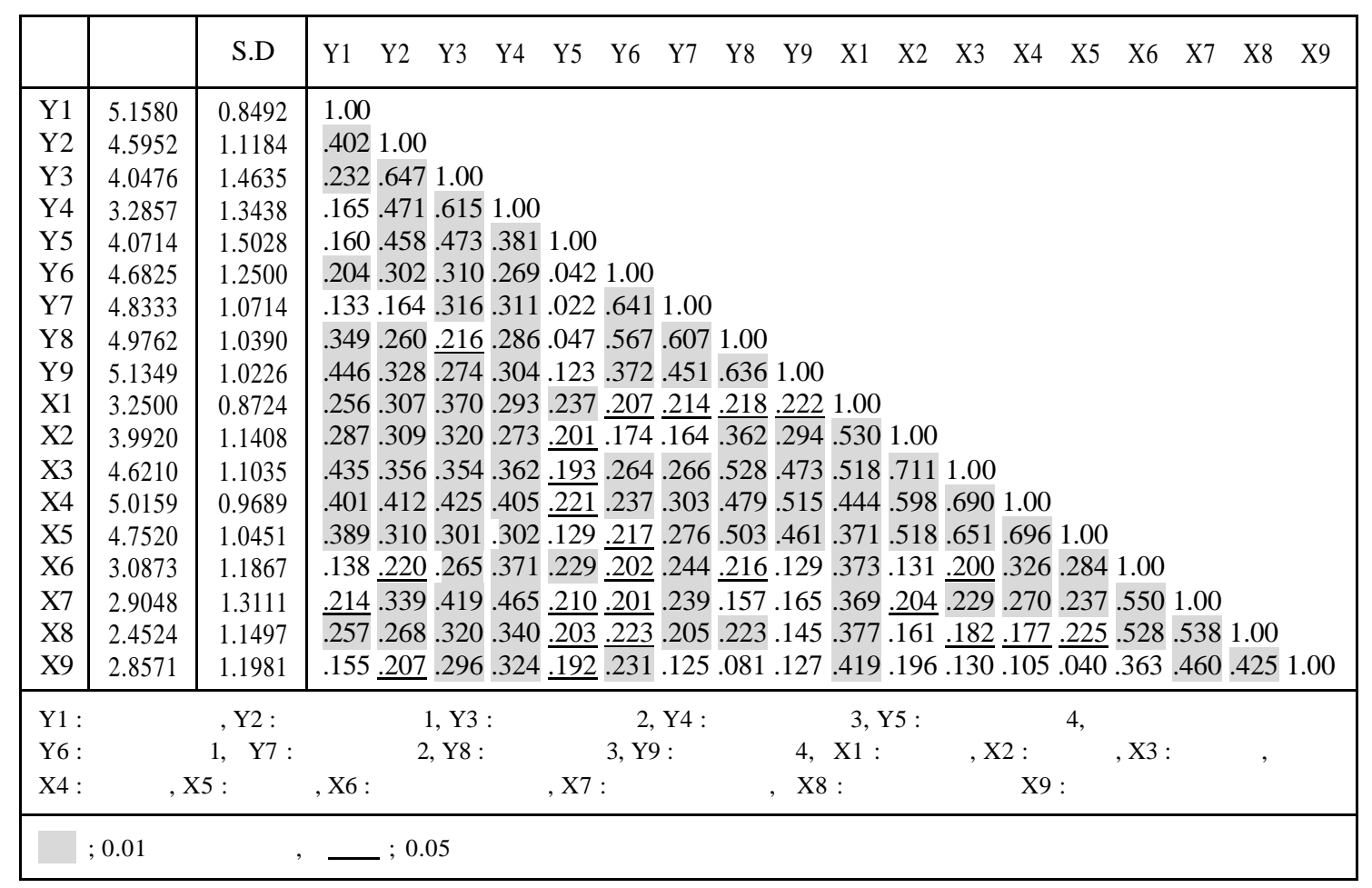

\section{2 가설의 검증}

(1) 모형의 적합도 검증

우선 제안된 모형이 실제자료와 얼마나 부합되는지를 나타내는 부합지수를 살펴보면, $\chi^{2}$ 는 198.89(d.f.=126, p=0.0005), 기초부합치(GFI : Goodness of Fit Index)는 0.86, 수정부합치 (AGFI : Adjusted Goodness Fit Index)는 0.81, 비교부합지수(CFI : Comparative Fit Index)는 0.93, 원소간평균차이(RMR)는 0.12 로서 뛰어난 모델이라 할 수는 없으나 어느 정도 자료에 부합 하는 모델인 것으로 나타났다.

(2) 각 가설에 대한 검증 및 논의

각 구성개념들간의 관계에 대한 가설을 검증한 결과 얻어진 <그림 4 >의 관계를 표로 나 타내면 <표 6>과 같다. 우선 종업원에게 제공되는 내부서비스품질이 상승하면 종업원의 서 비스능력이 상승할 것이라는 연구가설 1 과 종업원에게 제공되는 내부서비스품질이 증가하 면 종업원만족이 높아질 것이라는 연구가설 2 를 검증한 결과, <표 6>에서와 같이 내부서비 스품질이 서비스능력과 종업원만족에 유의한 정(+)의 효과를 미치는 것으로 나타나 연구가 
설 1 과 2 는 지지되었다.

<그림 4> LISREL 분석결과

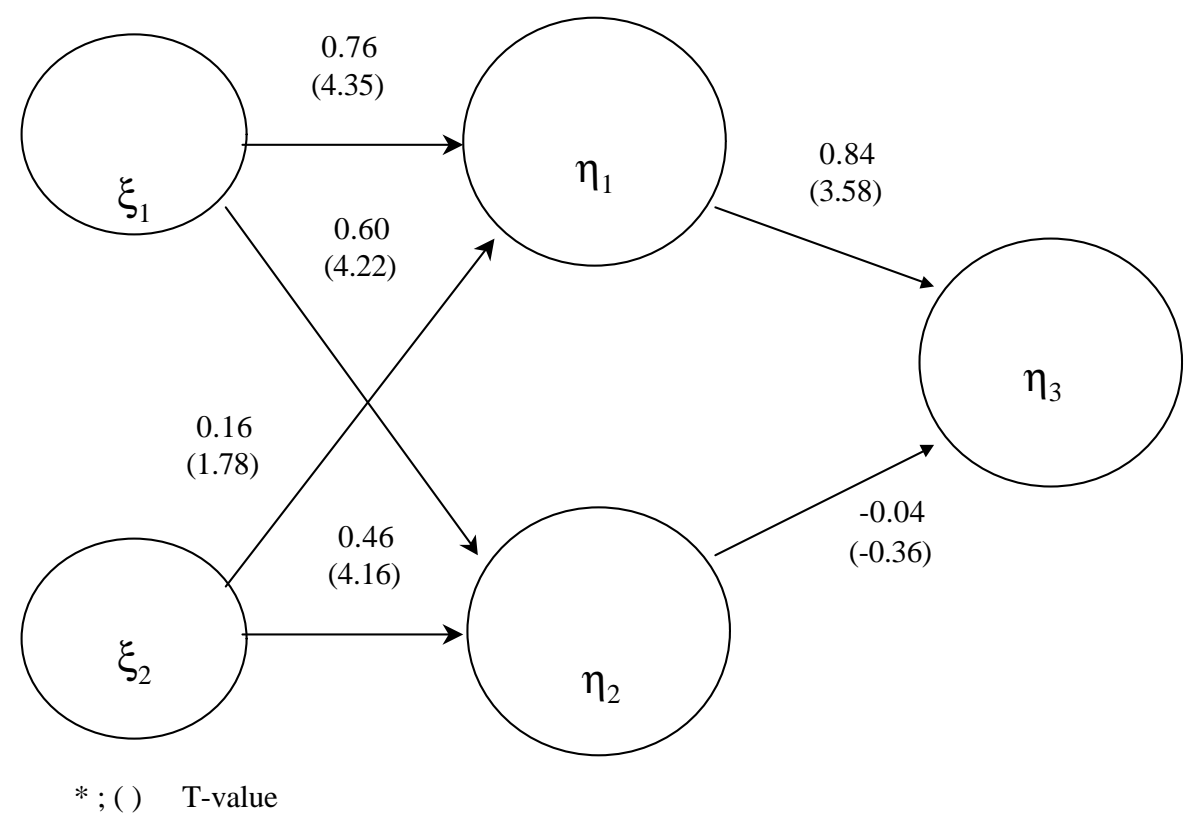

즉, 기업이 종업원들에게 좋은 서비스를 제공하게 되는 경우 종업원들이 보다 직무를 제 대로 수행할 수 있게 되며, 종업원들 스스로 고객들의 욕구에 제대로 부응할 수 있는 능력 을 가지게 되었다는 느낌, 즉 서비스능력 향상에 기여하게 되며, 이와 함께 종업원 만족도 함께 유발해낸다는 것으로, 이는 Hallowell 등 (1996)의 연구결과와 일치하는 것이다.

둘째, 서비스능력이 높아질수록 고객만족이 높아질 것이라는 연구가설 3 을 검증한 결과, 서비스능력이 고객만족에 유의한 정(+)의 영향을 미치는 것으로 나타나 연구가설 3 은 채택 되었다.

셋째, 종업원만족이 높아지면 고객만족이 높아질 것이라는 연구가설 4 를 검증한 결과, 통계적으로 유의하지 않아 연구가설 4 는 기각되었다.

<표 6> 각 구성개념들간의 관계분석 결과 


\begin{tabular}{|c|c|c|c|c|}
\hline 경로 & 경로명칭 & 경로계수 & 표준오차 & t 값 \\
\hline 내부서비스품질 $\left(\xi_{1}\right) \rightarrow$ 서비스능력 $\left(\eta_{1}\right)$ & $\gamma_{11}$ & 0.76 & 0.17 & $4.35^{*}$ \\
\hline 경제적요인 $\left(\xi_{2}\right) \rightarrow$ 서비스능력 $\left(\eta_{1}\right)$ & $\gamma_{12}$ & 0.16 & 0.09 & 1.78 \\
\hline 내부서비스품질 $\left(\xi_{1}\right) \rightarrow$ 종업원만족 $\left(\eta_{2}\right)$ & $\gamma_{21}$ & 0.60 & 0.14 & $4.22^{*}$ \\
\hline 경제적 요인 $\left(\xi_{2}\right) \rightarrow$ 종업원만족 $\left(\eta_{2}\right)$ & $\gamma_{22}$ & 0.46 & 0.11 & $4.16^{*}$ \\
\hline 서비스능력 $\left(\eta_{1}\right) \rightarrow$ 고객만족 $\left(\eta_{3}\right)$ & $\beta_{31}$ & 0.84 & 0.23 & $3.58^{*}$ \\
\hline 종업원만족 $\left(\eta_{2}\right) \rightarrow$ 고객만족 $\left(\eta_{3}\right)$ & $\beta_{32}$ & -0.04 & 0.11 & -0.36 \\
\hline$*$ 표시는 통계적으로 유의함을 가리킴 & & & & \\
\hline
\end{tabular}

마지막으로 종업원의 서비스능력과 종업원만족이 경제적 요인보다는 내부서비스품질과 같은 비경제적 요인에 의해 영향을 받을 것이라는 연구가설 5 와 6 을 검증한 결과, 종업원 의 서비스능력에 대해 내부서비스품질 $(\gamma=0.76)$ 이 경제조건 $(\gamma=0.16)$ 보다 큰 영향을 미치는 것으로 나타나 가설 5 는 채택되었다. 그러나 종업원만족에 대해서도 내부서비스품질 $(\gamma$ $=0.60)$ 이 경제조건 $(\gamma=0.46)$ 보다 더 큰 영향을 미치는 것으로 나타났지만 통계적으로 유의하 지 않아 가설 6 은 기각되었다. 이러한 결과는 종업원들의 서비스능력과 만족에 경제적인 요 인보다는 비경제적 요인 즉, 내부서비스품질의 영향력이 상대적으로 큰 것으로 나타나 이 부분에 대한 보다 많은 관심의 집중, 다시 말해서 효율적인 내부마케팅프로그램 전개의 필 요성을 부각시킨다고 할 수 있다.

\section{6. 결 론}

\section{1 연구결과의 요약 및 주요발견사항}

본 연구에서는 내부서비스품질에 대한 개념적 정의와 이의 측정방법을 알아보고, 종업원 들에게 제공되는 이러한 내부서비스품질이 종업원들의 서비스능력과 만족도에 어떠한 영향 을 미치며 이는 다시 고객만족과 어떠한 관련성을 가지는지를 알아보고, 이와 함께 종업원 의 서비스능력과 만족을 결정하는데 있어 경제적인 요인과 비교해서 상대적인 영향력이 어 떠한지를 알아보고자 하였다.

이론적 고찰과 이를 토대로 본 연구에서 제시된 연구가설들에 대한 실증분석의 결과와 시사점들은 다음과 같다. 
첫째, 종업원들에게 제공되는 내부서비스품질은 적용되는 조직과 시기에 따라서 그 구성 요인들이 상이할 수 있지만, 이와 관련된 선행 연구들을 종합하여 외부고객(external customer)들이 서비스품질 평가시 이용하는 속성들을 개발해냈던 방식으로 SERVQUAL 의 차 원으로 적용하여 그 측면(dimension)을 개발해낼 수 있었다. 물론 본 연구에서 이용한 SERVQUAL 의 척도들은 모든 서비스 산업에 범용화하는데 한계가 있을 수 있지만 기본적으 로 처음으로 실증규명을 하였다는 점에서 그 의의를 찾을 수 있다.

둘째, 종업원들에게 제공되는 내부서비스품질과 종업원들의 서비스능력 및 만족도와의 관계를 살펴본 결과 모두 유의한 정(+)의 영향을 미치는 것으로 나타나 종업원들의 서비스 능력을 개선시키고 그들의 만족도를 높이기 위해서는 종업원들에게 제공되는 내부서비스품 질을 제고할 필요가 있다는 점을 알 수 있었다. 결국 기업들이 체계적인 내부마케팅프로그 램을 전개해야만 한다는 시사점을 제공한다.

셋째, 종업원만족이 과연 고객만족에 유의한 영향을 미치는지를 알아보았는데, 본 연구에 서는 통계적으로 유의한 결과를 제시하지 못하였다. 그러나 양자간의 관계에 대한 선행 연 구들(Edvardsson et al 1997 ; Atkins et al. 1996; Schneider and Bowen 1993)은 대부분은 고객만족 은 만족한 종업원에 의해 달성된다는 점을 지적하고 있다. 즉, 서비스의 특성상 현장종업원 과 고객간의 상호작용이 필연적이게 되고, 이때 종업원들의 직무에 대한 만족이 떨어지게 되면 이는 고스란히 고객들에게 전달될 수밖에 없기 때문에 고객만족을 위해 종업원만족을 달성해야만 한다는 것이다.

넷째, 과연 종업원들의 서비스능력과 만족을 결정하는데 있어 경제적인 요인이 중요한지 내부서비스품질과 같은 비경제적인 요인이 중요한지에 대해서 살펴본 결과, 비경제적 요인, 즉 본 연구에서 살펴본 내부서비스품질이 서비스능력에 유의하게 더 큰 영향력을 미치고, 통계적으로 유의하지는 않았으나 종업원만족에도 더 큰 영향력을 미치는 것으로 나타났다. 이는 관리자들의 입장에서 종업원들의 서비스능력과 만족도를 제고하기 위해서는 임금이나 편익과 같은 경제적 요인보다는 그들에 대한 보다 많은 관심을 기울이는 등 내부서비스품질 을 제고하는데 주력해야 한다는 점을 시사해준다 하겠다.

\section{2 연구의 한계 및 향후 연구제안}

본 연구는 다음과 같은 한계점을 가지고 있으며, 이와 관련하여 향후의 연구제안을 하고 자 한다. 
첫째, 본 연구에서는 한 개의 병원만을 대상으로 설문조사를 실시하였고, 그에 따라 연구 표본의 수가 상당히 작은 문제가 나타나 본 연구의 일반화하는데 문제가 따랐다. 향후 연구 에서는 이러한 부분을 보완하여 연구를 진행할 필요가 있다.

둘째, 본 연구에서는 종업원의 대상을 간호사들만으로 국한하였으나, 기업이 전개해야 할 내부마케팅활동의 대상은 이들만이 아니다. 따라서 향후 연구에서는 현장종업원뿐만 아니라 지원부서의 종업원들까지도 함께 고려한 연구가 필요하다 하겠다.

셋째, 고객만족의 측정을 병원의 환자가 아닌 종업원인 간호사들의 지각을 통하여 측정 하였다는 점이다. 물론 이 과정에서 간호사들의 주관을 배제하기 위한 노력을 벌였지만, 향 후 연구에서는 설문대상을 달리하여 측정하는 방법을 고려해볼 필요가 있다.

넷째, 서비스품질이 가지는 기본적인 특성에 대한 것으로서 종단조사(longitudinal survey) 의 필요성이다. 고객들에게 제공되는 서비스품질과 마찬가지로 종업원들에게 제공되는 내부 서비스품질과 만족은 항상 일정한 것이 아니라 상황에 따라 매우 다양하게 변화할 수 있기 때문에 각 시기별로 종업원에게 제공되는 내부 서비스품질 및 만족에 대한 지각을 살펴봄으 로써 보다 나은 결론을 이끌 수 있을 것이다.

다섯째, 병원 관리자들에게 어떤 구체적인 내부서비스품질 요소들이 보다 중요하게 다루 어져야 할 것인지에 대한 제안을 하지는 못하였는데, 향후 연구에서는 내부서비스품질의 각 구성차원별로 서비스능력 및 종업원만족에 큰 영향을 미치는 변수가 무엇인지 규명할 필요 가 있겠다.

\section{참고문헌}

곽동성, 강기두 (1999), 서비스마케팅, 서울, 동성사

이학식, 김영, 이용기 (1998), "시장지향성과 성과: 사원만족, 고객만족 및 기업이미지의 매개 적역할," 경영학연구, 제 27 권 제 1 호, pp.157 184.

Atkins, P. M., B. S. Marshall, and R. G. Javalgi (1996), "Happy Employees Lead to Loyal Patients," Journal of Health Care Marketing, Vol.16, No.4, pp.15 23.

Berry, L. L. (1981), "The Employee as Customer," Journal of Retailing Banking, March, Vol.3, Iss.1, 
pp.33-41.

Berry, L. L. (1983), "Relationship Marketing," in Emerging Perspectives on Services Marketing, L. L. Berry, G. L. Shostack, and G. Upah, ed. Chicago, IL: American Marketing Association, pp.25 28.

Berry, L. L., and A. Parasuraman (1991), Marketing Services - Competing Through Quality, New York, Free Press, p.151.

Bowen, D. E., S. W. Gilliland, and R. Folger (1999), "HRM and Service Fairness: How Being Fair with Employees Spills Over to Customer," Organizational Dynamics, Winter, pp.7-23.

Cronin, J. J. Jr., and S. A. Taylor(1992) "Measuring Service Quality : A Reexamination and Extension," Journal of Marketing, Vol.56, July, pp.55 68.

Chaston, J. (1994), "Internal Customer Management and Service Gap within the UK Manufacturing Sector," International Journal of Operations and Production, Vol.14, No.9, pp.45 56.

Edvardsson, B., Edvinsson, L. and Nystr M, H. (1988) Internationalization in Knowledge-Intensive Service Companies - A Frame of Reference and Some Management Observations, Research Report presented at the 7th Annual Conference on Service Marketing, Arlington, Va., October, pp.2 5 .

Edvardsson, B., G. Larsson, and S. Setterlind (1997), "Internal Service Quality and the Psychological Work Environment: An Empirical Analysis of Conceptual Interrelations," The Service Industries Journal, Vol.17, No.2, April, pp.252 263.

Fosam, E. B., M. F. J. Grimsley and S. J. Wisher (1998), “Exploring model for employee satisfaction with particular reference to a police force," Total Quality Management, Vol.9, No.2-3, pp.235-247.

George, W. R., and C. Grönroos (1991), "Developing Customer-Conscious Employees at Every Level Internal Marketing," in the AMA Handbook of Marketing for the Service Industries, Carol A. congram, ed., New York: AMACOM, pp. $85 \sim 100$.

Gremler, D. D., M. J. Bitner, and K. R. Evans (1994), "The Internal Service Encounter," International Journal of Service Industry Management, Vol.5, No.2, pp.34 56.

Grönroos, C. (1990), Service Management and Marketing, Lexington, M.A.: Lexington Books.

Hallowell, R., L. A. Schlesinger, and J. Zornitsky (1996), "Internal Service Quality, Customer and Job Satisfaction: Linkages and Implications for Management, Human Resource Planning, Vol.19, No.2, pp. $20 \mathrm{~b} \sim 31$.

Heskett, J. L., and L. A. Schlesinger (1994), "Putting the Service-Profit Chain to Work," Harvard Business Review, Vol.72, No.2, March, pp.164 174 . 
Joseph, W. B. (1996), "Internal Marketing Builds Service Quality," Journal of Health Care Marketing, Vol.16, No.1, pp.54 59.

Kotler, P., and G. Amstrong (1991), Principles of Marketing, 5th ed., Englewood Cliffs, NJ: PrenticeHall, p.607.

Parasuraman, A., L. L. Berry, and V. A. Zeithaml (1993), "More on Improving Service Quality Measurement," Journal of Retailing, Vol.67, No.4. pp.420 450.

Rosenbluth, Hal (1991), "Tales from a Nonconformist Company," Harvard Business Review, JulyAugust, pp. $26 \sim 36$.

Rosenbluth, H., and D. M. Peters (1992), Customer Comes Second and Other Secrets of Exceptional Service, New York, Morrow.

Rust, R. T., G. L. Stewart, H. Miller, and D. Pielack (1996), "The satisfaction and retention of frontline employees," International Journal of Service Industry Management, Vol.7, pp.62 80.

Schlesinger, L. A., and J. L. Heskett (1991), "The Service-driven Company," Harvard Business Review, September-October, pp.71 81.

Schneider, B, and D. E. Bowen (1993), "The Service Organization: Human Resources Management is Crucial," Organizational Dynamics, Spring, Vol.21, Iss.4, pp.39-52.

Silvia, S. (1988), Effect of Sampling Error and Model Misspecification on Goodness-of-Fit Indices for Structural Equation Model, Ph. D. Dissertation, Ohio State University

Stanley, L. L., and J. D. Wisner (1998), "Internal Service Quality in Purchasing An Empirical Study," International Journal of Purchasing and Materials Management, Summer pp.50 60.

Zeithaml, V. A., A. Parasuraman, and L. L. Berry (199), Delivering Quality Service: Balancing customer perceptions and expectation, The Free Press. 